\title{
ANALISIS REAKSI PASAR MODAL BAGI PERUSAHAAN DALAM INDEKS IDX30 TERHADAP KEMENANGAN DONALD TRUMP PADA PEMILIHAN PRESIDEN AMERIKA SERIKAT
}

\author{
Efata Putri ${ }^{1}$ \\ Andini Nurwulandari ${ }^{2}$ \\ ${ }^{1,2}$ Fakultas Ekonomi dan Bisnis Universitas Nasional
}

Email: efata.putri@gmail.com, andin_manajemen@yahoo.com

\begin{abstract}
ABSTRAK
Penelitian ini bertujuan untuk menganalisis reaksi pasar bagi perusahaan yang terdaftar dalam Indeks IDX30 terhadap kemenangan Donald Trump pada pemilihan umum Presiden Amerika Serikat. Dalam hal ini, reaksi pasar diukur dengan membandingkan nilai rata-rata harga, abnormal return, dan volume perdagangan saham pada periode sebelum dan sesudah peristiwa. Dengan menggunakan sampel berupa 30 perusahaan yang terdaftar di Indeks IDX30 selama periode Agustus 2016 - Januari 2017, hasil penelitian menunjukkan bahwa harga saham dan abnormal return pada periode sesudah kemenangan Donald Trump memiliki nilai yang lebih kecil secara signifikan daripada sebelum peristiwa tersebut, sementara volume perdagangan saham pada periode sesudah kemenangan Donald Trump justru tidak tidak berbeda secara signifikan daripada periode sebelumnya.
\end{abstract}

Kata kunci: Kemenangan Donald Trump, harga saham, return tidak normal, volume perdagangan saham, dan studi peristiwa

\begin{abstract}
This study aims to analyze the market reaction for companies listed on the IDX30 Index to Donald Trump's victory in the United States Presidential election. In this case, the market reaction is measured by comparing the average value of stock prices, abnormal returns, and stock trading volume in the period before and after the event. Using a sample of 30 companies listed on the IDX30 Index during the period August 2016 - January 2017, the results showed that stock prices and abnormal returns in the period after Donald Trump's victory had a significantly smaller value than before the event, while stock trading volume in the period after Donald Trump's victory did not differ significantly from the previous period.
\end{abstract}

Keywords: $\quad$ Donald Trump victory, stock price, abnormal return, stock trading volume

\section{PENDAHULUAN}

Pasar modal merupakan wadah yang mempertemukan para investor dengan perusahaan. Dalam hal ini, pasar modal memfasilitasi pemindahan dana dari pihak yang berkelebihan dana kepada pihak yang membutuhkannya. Hal tersebut memungkinkan investor untuk meminjamkan uangnya kepada perusahaan yang membutuhkan dana dengan harapan akan mendapatkan imbalan atas uang yang dipinjamkannya tersebut. Di 
sisi lain, perusahaan yang membutuhkan dana tersebut dapat menjalankan kegiatannya dengan tanpa harus menunggu dana dari hasil operasinya (Pratama dkk, 2015).

Dibandingkan dengan return yang diperoleh dari bentuk investasi lainnya, investasi di pasar modal juga memberikan return yang cenderung lebih tinggi. Akan tetapi, tingkat ketidakpastian pada investasi di pasar modal juga cenderung lebih tinggi daripada bentuk investasi lainnya. Dalam hal ini, tingginya return yang diterima dari suatu investasi akan sebanding dengan tingginya risiko yang ditanggung. Oleh sebab itu, investor perlu untuk mengumpulkan informasi terkait pasar modal dalam upaya mengurangi risiko yang ditanggungnya dari keputusan investasi yang diambilnya (Melati dan Nurwulandari, 2017).

Menurut Alwi (2008:87), berbagai isu dari luar negeri juga merupakan salah satu faktor eksternal yang bisa mempengaruhi pasar modal. Dalam kaitannya dengan hal ini, peristiwa kemenangan Donald Trump sebagai Presiden Amerika Serikat (AS) yang ke-45 pada November 2016 menjadi suatu isu besar yang efeknya berpengaruh secara global. Kemenangan ini tidak terprediksi sebelumnya karena banyak orang memprediksi Hillary Clinton yang akan memenangkan pemilihan tersebut.

Bagi Indonesia, gejolak peristiwa yang terjadi di AS seringkali menimbulkan efek yang cukup signifikan. Dalam hal ini, naik turunnya harga pada pasar saham AS seringkali berpengaruh signifikan terhadap pasar saham Indonesia. Hal tersebut terjadi karena AS itu sendiri merupakan tujuan ekspor non-minyak terbesar bagi Indonesia. Apabila AS sedang mengalami resesi, maka hal ini akan menimbulkan dampak terhadap ekspor Indonesia yang akan menurun karena konsumen dari negara tersebut mengalami penurunan daya beli (Sagita, 2017).

Selain menjadi tujuan ekspor terbesar bagi Indonesia, AS juga merupakan negara dengan perekonomian terbesar di dunia. Hal tersebut didasarkan atas data pada tahun 2015 yang menunjukkan bahwa Produk Domestik Bruto (PDB) AS berjumlah sebesar 24,42\% dari total keseluruhan PDB dunia. Hal ini jelas membuktikan bahwa perubahan perekonomian pada negara tersebut pada akhirnya bisa mempengaruhi perekonomian Indonesia, baik melalui ekspor-impor barang dan jasa, ataupun melalui aliran dana investasi dari investor (Wadrianto, 2016).

Pada tanggal 9 November 2016, saat ditetapkannya Donald Trump sebagai pemenang dalam pemilihan umum Presiden AS, nilai di pasar Indonesia langsung menunjukkan terjadinya penurunan. Dalam hal ini, IHSG turun sebanyak 56,36 poin menjadi 5.414,32 pada penutupan bursa harian tanggal 9 November 2016 Indeks IDX30 
itu sendiri bahkan mengalami penurunan sebanyak 90 poin ke angka 4.692,70 dari 4.699,79. Berdasarkan hal tersebut, perlu dianalisis lebih lanjut apakah pasar Indonesia secara signifikan memberikan reaksi yang negatif bagi perusahaan yang terdaftar di Indeks IDX30 tersebut terhadap peristiwa kemenangan Donald Trump. Oleh sebab itu, dilakukan penelitian untuk menganalisis reaksi pasar terhadap peristiwa tersebut pada perusahaan dalam Indeks IDX30 beserta signifikansi reaksinya.

\section{TINJAUAN PUSTAKA}

\section{Pasar Modal}

Berdasarkan UU No. 21 Tahun 2011 tentang OJK, pasar modal adalah kegiatan yang bersangkutan dengan penawaran umum dan perdagangan efek, perusahaan publik yang berkaitan dengan efek diterbitkannya, serta lembaga dan profesi yang berkaitan dengan efek sebagaimana dimaksud dalam Undang-undang No.8 Tahun 1995 tentang pasar modal.

\section{Efisiensi Pasar Modal}

Efisiensi pasar ditunjukkan sebagai hubungan antara harga sekuritas saham dengan ketersediaan informasi (Bailey dan Chung, 1995). Dalam pasar yang efisien, harga akan sepenuhnya mencerminkan informasi yang tersedia, sehingga harga itu sendiri akan bereaksi tanpa bias terhadap berbagai informasi baru (Fama, 1970). Jogiyanto (2016) lebih lanjut menyebutkan bahwa pasar yang efisien merupakan pasar yang bereaksi secara cepat dan akurat terhadap informasi dan dengan segera membentuk harga keseimbangan baru.

Fama (1970) dalam Jogiyanto (2016) mengklasifikan efisiensi pasar ke dalam tiga bentuk utama, yakni sebagai berikut.

\section{Efisiensi Pasar Bentuk Lemah (Weak Form)}

Pasar dinyatakan efisien dalam bentuk lemah jika harga dari saham-sahamnya secara penuh mencerminkan informasi masa lalu. Bentuk efisiensi ini sangat berhubungan dengan random walk theory yang menyatakan bahwa data masa lalu tidak bisa dikaitkan dengan nilai saat ini. Akibatnya, nilai di masa lalu tidak bisa dipergunakan untuk memprediksi harga saat ini. 
2. Efisiensi Pasar Bentuk Setengah Kuat (Semi-Strong Form)

Pasar dinyatakan efisien setengah kuat apabila harga saham-sahamnya saham secara penuh mencerminkan seluruh informasi yang dipublikasikan, termasuk berbagai informasi dalam laporan keuangan.

3. Efisiensi Pasar Bentuk Kuat (Strong Form)

Pasar dinyatakan efisien dalam bentuk kuat jika harga saham-sahamnya secara penuh mencerminkan semua informasi yang tersedia, termasuk informasi yang sangat rahasia sekalipun.

\section{Harga Saham}

Harga saham adalah harga pasar yang setiap hari tercatat pada saat penutupan (closing price) dari suatu saham. Adapun harga saham dikalikan dengan jumlah saham yang diterbitkan (outstanding shares) dapat disebut sebagai nilai kapitalisasi pasar (market capitalization) (Jogiyanto, 2016).

\section{Volume Perdagangan Saham}

Volume perdagangan saham atau (trading volume activity) merupakan instrumen yang bisa dipergunakan untuk mengetahui reaksi pasar modal terhadap informasi melalui parameter berupa volume saham yang diperdagangkan di pasar tersebut (Sutrisno, 2000). Volume perdagangan saham ialah rasio antara jumlah lembaran saham yang diperdagangkan pada waktu tertentu terhadap jumlah saham yang beredar pada waktu tertentu (Husnan, 2010).

\section{Abnormal Return}

Menurut Jogiyanto (2016), abnormal return adalah selisih antara return sesungguhnya (actual return) dengan return yang diekspektasikan (expected return). Samsul (2010:275) menyebutkan bahwa abnormal return itu sendiri tidak hanya dapat timbul setelah suatu informasi diterbitkan secara resmi, tetapi dapat pula timbul sebelum diterbitkannya informasi tersebut karena adanya kebocoran informasi.

Brown dan Warner (1985) dalam Jogiyanto (2016:648) menyebutkan bahwa expected return bisa diukur menggunakan tiga model berikut. 


\section{Mean Adjusted Model}

Mean adjusted model beranggapan bahwa expected return bernilai konstan yang sama dengan rata-rata actual return sebelumnya selama periode estimasi.

\section{Market Model}

Dalam model ini, expected return dihitung melalui dua tahap, yakni tahapan pembentukan model ekspektasi menggunakan data realisasi selama periode estimasi dan tahapan pengestimasian expected return di periode jendela menggunakan model ekspektasi yang dibentuk pada tahap pertama tersebut. Model ekspektasi ini bisa dibentuk menggunakan regresi OLS (Ordinary Least Square).

\section{Market Adjusted Model}

Model ini beranggapan bahwa penduga terbaik untuk mengestimasi return saham adalah return dari indeks pasar pada saat yang sama. Dengan mempergunakan model ini, periode estimasi tidak perlu dipergunakan untuk membentuk model estimasi karena return saham yang diestimasi pada dasarnya sama dengan return indeks pasar.

\section{Indeks IDX30}

Indeks IDX30 merupakan indeks yang mencakup 30 saham yang konstituennya dipilih dari konstituen Indeks LQ45. Konstituen Indeks LQ45 itu sendiri dipilih karena saat ini indeks tersebut sudah bisa menggambarkan kinerja saham berlikuiditas dan berkapitalisasi pasar tinggi, tetapi beberapa fund manager menganggap jumlah 45 saham tersebut sebagai jumlah yang terlalu besar. Jumlah konstituen Indeks IDX30 yang mencakup 30 saham dinilai lebih unggul karena lebih mudah dilakukan replika sebagai acuan portofolio. Oleh sebab itu, indeks IDX30 dikembangkan untuk memudahkan investor dan berbagai pelaku pasar terkait dalam mengawasi kinerja dan pergerakan harga saham yang menjadi acuan indeksnya tersebut (Roszhandi, 2012).

\section{Pengembangan Hipotesis Penelitian}

Gejolak peristiwa yang terjadi di AS seringkali menimbulkan efek yang cukup signifikan bagi Indonesia. Dalam hal ini, naik turunnya harga pada pasar saham AS seringkali berpengaruh signifikan terhadap pasar saham Indonesia. Hal tersebut terjadi karena AS itu sendiri merupakan tujuan ekspor non-minyak terbesar bagi Indonesia. Apabila AS sedang mengalami resesi, maka hal ini akan menimbulkan dampak terhadap 
ekspor Indonesia yang akan menurun karena konsumen dari negara tersebut mengalami penurunan daya beli (Sagita, 2017).

Selain mampu mempengaruhi perekonomian Indonesia melalui ekspor-impor barang dan jasa, AS juga mampu mempengaruhi perekonomian Indonesia melalui aliran dana investasi dari para investor. Hal ini terjadi karena AS itu sendiri merupakan negara dengan perekonomian terbesar di dunia yang mencatatkan PDB dengan nilai setara dengan 24,42\% dari total keseluruhan PDB dunia berdasarkan data per tahun 2015 (Wadrianto, 2016).

Berdasarkan penjelasan di atas, maka peristiwa penting yang terjadi di AS, termasuk peristiwa kemenangan Donald Trump pada pemilihan umum Presiden AS, yang dapat secara langsung mempengaruhi pergerakan harga pada pasar saham AS itu sendiri dinilai berpotensi untuk mempengaruhi pergerakan harga pada pasar saham Indonesia. Hal tersebut pada akhirnya juga akan mempengaruhi abnormal return dan volume perdagangan dari saham yang ditransaksikan di pasar tersebut.

Dalam hal ini, pasar dinilai dapat menunjukkan reaksi yang negatif terhadap kemenangan Donald Trump karena peristiwa itu sendiri merupakan suatu kejadian yang tidak terduga dan bertolak belakang dari spekulasi maupun perkiraan sebelumnya. Selain itu, Donald Trump dengan seluruh kontroversi, yang di antaranya mencakup rencana yang dikemukakannya untuk mengurangi impor dan melarang pengungsi negara Timur Tengah untuk masuk ke AS dinilai akan menimbulkan keraguan di kalangan masyarakat atas kepemimpinannya. Akibatnya, harga, abnormal return, dan volume perdagangan saham di Indonesia, yang dalam hal ini direpresentasikan oleh saham dari perusahaan-perusahaan yang terdaftar di IDX30, diduga mengalami penurunan yang signifikan sesudah kemenangan Donald Trump tersebut.

Berdasarkan uraian di atas, hipotesis penelitian ini dirumuskan sebagai berikut.

$\mathrm{H}_{1}$ : Rata-rata harga saham sesudah kemenangan Donald Trump lebih kecil secara signifikan daripada rata-rata harga saham sebelum peristiwa tersebut.

$\mathrm{H}_{2}$ : Rata-rata abnormal return sesudah kemenangan Donald Trump lebih kecil secara signifikan daripada rata-rata abnormal return sebelum peristiwa tersebut.

$\mathrm{H}_{3}$ : Rata-rata volume perdagangan saham sesudah kemenangan Donald Trump lebih kecil secara signifikan daripada rata-rata volume perdagangan saham sebelum peristiwa tersebut. 


\section{METODOLOGI PENELITIAN}

\section{Sumber dan Jenis Data}

Data dalam penelitian ini diambil dari sumber-sumber sekunder, yakni dari situs Bursa Efek Indonesia dan Yahoo Finance. Adapun jenis data yang dipergunakan ialah data kuantitatif dalam bentuk panel karena diamati selama kurun periode pengamatan tertentu pada seluruh perusahaan yang dijadikan sebagai sampel penelitian.

\section{Populasi dan Sampel}

Populasi dan sampel data dalam penelitian ini adalah emiten yang terdaftar dalam Indeks IDX30 pada periode Agustus 2016 s.d. Januari 2017, yakni saat peristiwa sedang berlangsung. Pemilihan emiten yang terdaftar dalam indeks IDX30 sebagai populasi penelitian itu sendiri terjadi karena tidak seluruh saham emiten yang terdaftar di BEI aktif diperdagangkan. Dalam hal ini, indeks IDX30 dipilih karena dinilai telah mampu untuk menggambarkan kinerja saham berlikuiditas tinggi dan berkapitalisasi pasar besar.

Adapun sampling dilakukan menggunakan metode purposive sampling, yakni dengan kriteria yang mengharuskan perusahaan untuk memiliki data pasar dan laporan keuangan yang lengkap selama periode pengamatan.

\section{Definisi Operasional Dan Pengukuran Variabel}

\section{Kemenangan Donald Trump}

Dalam penelitian ini, yang dimaksud dengan kemenangan Donald Trump adalah peristiwa kemenangan Donald Trump dalam pemilihan umum Presiden AS yang diselenggarakan pada 8 November 2016.

\section{Harga Saham}

Harga saham yang dimaksudkan dalam penelitian ini adalah closing price, yakni harga pasar dari suatu saham pada waktu penutupan bursa harian.

\section{Volume Perdagangan Saham}

Volume perdagangan saham yang dimaksudkan dalam penelitian ini adalah rasio antara jumlah saham yang diperdagangkan dengan jumlah saham yang beredar.

$$
\text { TVAit }=\frac{\sum \text { saham i yang diperdagangkan pada hari ke-t }}{\sum \text { saham i yang beredar pada hari ke-t }}
$$




\section{Abnormal Return}

Abnormal return yang dimaksudkan dalam penelitian ini adalah selisih antara actual return dan market return, dimana actual return itu sendiri merupakan perbandingan antara selisih harga saham periode ke-t dengan periode sebelumnya, sementara market return merupakan perbandingan antara selisih IHSG periode ke-t dengan periode sebelumnya.

$$
\mathrm{AR}_{\mathrm{it}}=\mathrm{R}_{\mathrm{it}}-\mathrm{R}_{\mathrm{mt}}
$$

Keterangan:

$\mathrm{AR}_{\mathrm{it}} \quad=$ Abnormal return saham i pada periode peristiwa ke- $\mathrm{t}$

$\mathrm{R}_{\mathrm{it}} \quad=$ Return realisasi saham i pada periode peristiwa ke- $\mathrm{t}$

$\mathrm{R}_{\mathrm{mt}} \quad=$ Return pasar

$$
R_{i t}=\frac{P_{i t}-P_{i t-1}}{P_{i t-1}}
$$

Keterangan:

$\mathrm{P}_{\mathrm{it}} \quad=$ Harga saham i pada periode peristiwa ke-t

$\mathrm{P}_{\mathrm{it}-1} \quad=$ Harga saham $\mathrm{i}$ pada periode peristiwa ke $\mathrm{t}-1$

$$
\mathrm{Rmt}=\frac{\text { IHSGt-IHSGt-1 }}{\text { IHSGt-1 }}
$$

Keterangan:

$\begin{array}{ll}\mathrm{IHSG}_{\mathrm{t}} & =\text { Indeks Harga Saham Gabungan pada periode peristiwa ke-t } \\ \mathrm{IHSG}_{\mathrm{t}-1} & =\text { Indeks Harga Saham Gabungan pada periode peristiwa ke-t-1 }\end{array}$

\section{Metode Analisis}

Pengolahan serta penganalisisan data penelitian ini dilakukan menggunakan uji beda dua rata-rata (t-test) dengan SPSS 17.0. Sebelum dilakukan uji beda, data penelitian juga terlebih dahulu diuji normalitasnya. Adapun teknik analisis yang dipergunakan adalah event study dengan event window berupa 10 hari sebelum kemenangan Donald Trump ( $\mathrm{t}-$ 10 s.d. $\mathrm{t}-1)$ dan 10 hari sesudah kemenangan Donald Trump ( $t+1$ s.d. $\mathrm{t}+10)$. 


\section{HASIL PENELITIAN DAN PEMBAHASAN}

\section{Hasil Penelitian}

1. Hasil Uji Normalitas

Hasil uji normalitas menunjukkan bahwa data rata-rata harga saham, abnormal return, dan volume perdagangan saham berdistribusi normal sebagaimana yang ditunjukkan pada tabel berikut ini.

\section{Tabel 1 Hasil Uji Normalitas}

\begin{tabular}{|c|c|c|c|c|c|c|c|c|c|}
\hline \multirow{2}{*}{ Periode } & \multicolumn{3}{|c|}{ Harga Saham } & \multicolumn{3}{c|}{ Abnormal Return } & \multicolumn{3}{c|}{ Volume Perdagangan } \\
\cline { 2 - 11 } & \multicolumn{3}{|c|}{ Shapiro-Wilk } & \multicolumn{3}{c|}{ Shapiro-Wilk } & \multicolumn{3}{c|}{ Shapiro-Wilk } \\
\cline { 2 - 11 } & Statistic & df & Sig. & Statistic & df & Sig. & Statistic & df & Sig. \\
\hline Sebelum & 0.906 & 10 & 0.256 & 0.875 & 10 & 0.113 & 0.831 & 10 & 0.340 \\
\hline Sesudah & 0.780 & 10 & 0.080 & 0.831 & 10 & 0.330 & 0.874 & 10 & 0.110 \\
\hline
\end{tabular}

(Sumber: Data diolah, 2018)

Berdasarkan tabel di atas, data harga saham, abnormal return, dan volume perdagangan saham pada periode sebelum dan sesudah kemenangan Donald Trump memiliki Sig. yang lebih besar dari 5\%, sehingga data tersebut terbukti terdistribusi normal dan uji hipotesis pun dapat dilanjutkan menggunakan uji beda.

\section{Hasil Uji Hipotesis}

\section{Tabel 2 Hasil Uji Hipotesis}

\begin{tabular}{clcc}
\hline Variabel & Periode & Sig. (2-tailed) & Keterangan \\
\hline \hline \multirow{2}{*}{ Harga Saham } & & & \\
& HG_Sebelum & .000 & $\mathrm{H}_{1}$ diterima \\
Abnormal Return & $\begin{array}{l}\text { HG_Sesudah } \\
\text { AR_Sebelum }\end{array}$ & .000 & $\mathrm{H}_{2}$ diterima \\
Trading Volume & AR_Sesudah & & \\
& TV_Sebelum & .079 & $\mathrm{H}_{0}$ diterima \\
& TV_Sesudah & &
\end{tabular}

(Sumber: Data diolah, 2018)

Berdasarkan tabel di atas, dapat disimpulkan bahwa $\mathrm{H}_{1}$ dan $\mathrm{H}_{2}$ diterima karena pengujian pada setiap hipotesis tersebut menghasilkan nilai Sig. yang lebih kecil daripada $5 \%$, sementara $\mathrm{H}_{3}$ justru ditolak karena nilai Sig. yang dihasilkan dari pengujian hipotesis tersebut memiliki nilai yang lebih besar daripada 5\%. Hal ini menunjukkan bahwa harga saham dan abnormal return pada periode sesudah kemenangan Donald Trump memiliki nilai yang lebih kecil secara signifikan daripada sebelum peristiwa tersebut, sementara volume perdagangan saham pada periode sesudah kemenangan Donald Trump justru tidak memiliki nilai yang lebih kecil secara signifikan daripada sebelum peristiwa tersebut atau 
dengan kata lain, volume perdagangan saham pada periode sesudah kemenangan Donald Trump justru tidak berbeda secara signifikan daripada periode sebelumnya.

\section{Pembahasan}

\section{Penurunan Harga Saham Sesudah Kemenangan Donald Trump}

Berdasarkan hasil dari pengujian hipotesis yang telah dilakukan sebelumnya, dapat diketahui bahwa harga saham sesudah kemenangan Donald Trump lebih kecil secara signifikan daripada sebelum peristiwa tersebut. Hal tersebut menunjukkan bahwa harga saham mengalami penurunan yang signifikan sesudah kemenangan Donald Trump, yakni sebagaimana yang ditunjukkan pada gambar berikut.

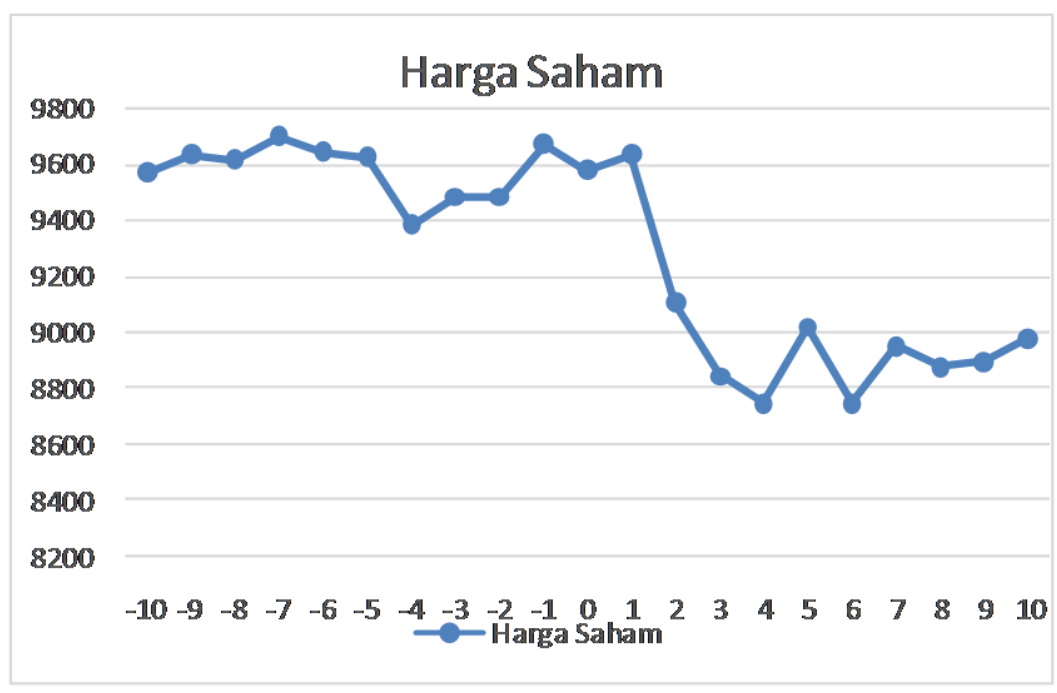

(Sumber: Data diolah, 2018)

\section{Gambar 1. Pergerakan Harga Saham}

\section{Sebelum dan Sesudah Kemenangan Donald Trump}

Kemenangan Donald Trump sebagai presiden dan Mike Pence sebagai wakil presiden terpilih AS, adalah kejadian yang tidak terduga. Masyarakat AS maupun global sangat terkejut dengan hasil yang bertolak belakang dari spekulasi maupun perkiraan sebelumnya. Donald Trump dengan seluruh kontroversi, yang di antaranya mencakup rencana yang dikemukakannya untuk mengurangi impor dan melarang pengungsi negara Timur Tengah untuk masuk ke AS dinilai akan menimbulkan keraguan di kalangan masyarakat atas kepemimpinannya.

Berdasarkan signalling theory, penurunan harga saham tersebut disebabkan oleh reaksi negatif investor terhadap informasi mengenai kemenangan Donald Trump yang 
sekaligus menunjukkan pesimisme mereka terhadap prospek kerja Donald Trump di masa mendatang. Dalam hal ini, investor menahan diri untuk tidak melakukan transaksi, terutama transaksi beli saham. Rendahnya permintaan dan transaksi yang dilakukan di bursa pada akhirnya mengakibatkan terjadinya penurunan terhadap harga saham.

Sebagaimana dikutip dari Sagita (2017), respon negatif pasar modal terhadap kemenangan Donald Trump terjadi karena para investor mengalami kepanikan yang membuat mereka kembali mengevaluasi aset mereka di pasar modal. Dalam hal ini, investor merasa khawatir atas ketidakpastian tentang aturan perdagangan, imigrasi penduduk, dan masalah politik yang melekat pada Trump. Hal tersebut pada akhirnya turut memberikan dampak yang signifikan pula terhadap pasar Indonesia berupa penurunan harga saham yang signifikan pasca kemenangan Donald Trump tersebut.

\section{Penurunan Abnormal Return Sesudah Kemenangan Donald Trump}

Berdasarkan hasil dari pengujian hipotesis yang telah dilakukan sebelumnya, dapat diketahui bahwa abnormal return sesudah kemenangan Donald Trump lebih kecil secara signifikan daripada sebelum peristiwa tersebut. Hal tersebut menunjukkan bahwa abnormal return mengalami penurunan yang signifikan sesudah kemenangan Donald Trump, yakni sebagaimana yang ditunjukkan pada gambar berikut.

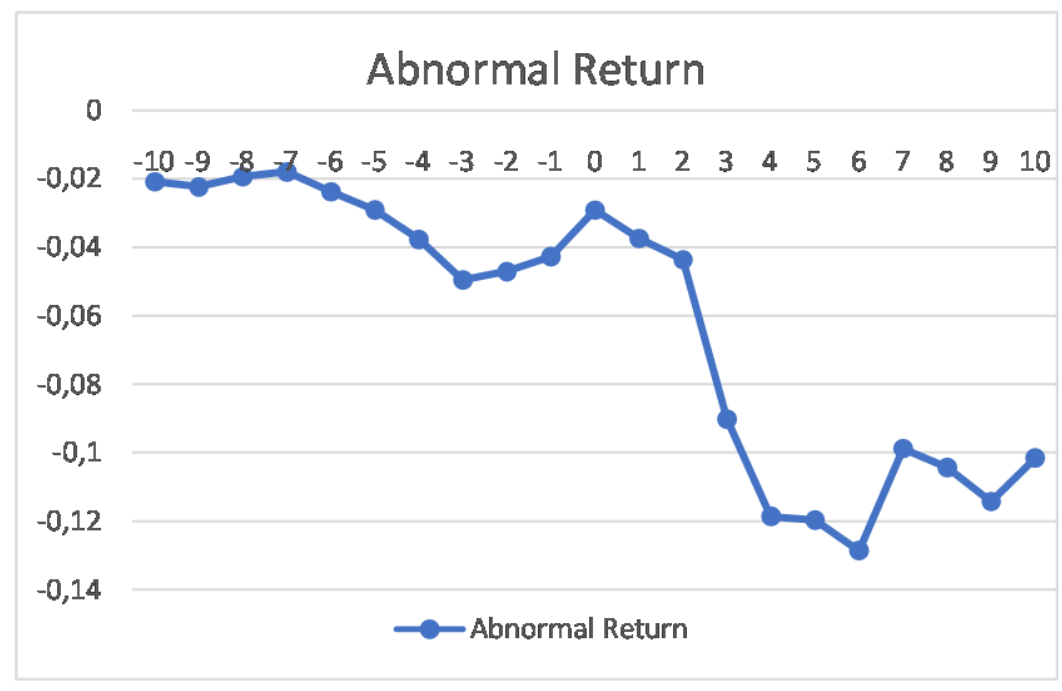

(Sumber: Data diolah, 2018)

Gambar 1. Pergerakan Abnormal Return Sebelum dan Sesudah Kemenangan Donald Trump 
Fenomena penurunan abnormal return sesudah kemenangan Donald Trump terjadi beriringan dengan pergerakan harga saham yang juga menunjukkan adanya penurunan. Berdasarkan signalling theory, penurunan abnormal return tersebut disebabkan oleh reaksi negatif investor terhadap informasi mengenai kemenangan Donald Trump yang sekaligus menunjukkan pesimisme mereka terhadap prospek kerja Donald Trump di masa mendatang. Dalam hal ini, investor menahan diri untuk tidak melakukan transaksi, terutama transaksi beli saham. Rendahnya permintaan dan transaksi yang dilakukan di bursa tersebut kemudian mengakibatkan terjadinya penurunan terhadap harga saham yang pada akhirnya menimbulkan terjadinya penurunan abnormal return.

Sebagaimana dikutip dari Sagita (2017), respon negatif pasar modal terhadap kemenangan Donald Trump terjadi karena para investor mengalami kepanikan yang membuat mereka kembali mengevaluasi aset mereka di pasar modal. Dalam hal ini, investor merasa khawatir atas ketidakpastian tentang aturan perdagangan, imigrasi penduduk, dan masalah politik yang melekat pada Trump. Hal tersebut pada akhirnya turut memberikan dampak yang signifikan pula terhadap pasar Indonesia berupa penurunan abnormal return saham yang signifikan pasca kemenangan Donald Trump tersebut.

\section{Tidak Adanya Perbedaan Volume Perdagangan Saham Sebelum dan Sesudah Kemenangan Donald Trump}

Berdasarkan hasil dari pengujian hipotesis yang telah dilakukan sebelumnya, dapat diketahui bahwa tidak terdapat perbedaan volume perdagangan saham yang signifikan pada periode sebelum dan sesudah kemenangan Donald Trump. Hal tersebut menunjukkan bahwa kemenangan Donald Trump tidak menimbulkan dampak yang signifikan terhadap pergerakan likuiditas saham.

Hasil penelitian ini sejalan dengan hasil yang ditemukan oleh Nambela (2017) pada empat sektor khusus, yakni sektor pertanian, sektor industri dasar dan kimia, sektor industri barang konsumsi, dan sektor keuangan. Dalam penelitiannya, Nambela (2017) menemukan bahwa peristiwa terpilihnya Donald Trump sebagai Presiden AS tidaklah mempengaruhi volume perdagangan saham secara signifikan pada keempat sektor tersebut.

Tidak adanya perbedaan volume perdagangan saham yang signifikan sebelum dan sesudah kemenangan Donald Trump menunjukkan bahwa investor cenderung tidak melakukan banyak transaksi sesudah peristiwa tersebut. Dalam hal ini, investor cenderung 
untuk menunggu sampai dilantiknya Donald Trump sebagai Presiden karena dalam membuat keputusan yang berkaitan dengan transaksi di pasar modal, investor ingin terlebih dahulu mengetahui kebijakan apa yang akan dilakukan oleh Donald Trump sebagai Presiden AS dan signifikansinya terhadap kondisi pasar di Indonsia. Dengan kata lain, sikap wait and see ini terjadi karena pada rentang waktu periode pengamatan dalam penelitian ini,Trump belum mempunyai kewenangan untuk mengambil keputusan atau kebijakan apapun yang berdampak pada pasar modal Indonesia.

\section{KESIMPULAN DAN SARAN}

\section{Kesimpulan}

Berikut ini merupakan kesimpulan yang diambil berdasarkan hasil penelitian ini.

1. Hal ini menunjukkan bahwa harga saham pada periode sesudah kemenangan Donald Trump memiliki nilai yang lebih kecil secara signifikan daripada sebelum peristiwa tersebut atau dengan kata lain, terjadi penurunan harga saham yang signifikan sesudah kemenangan Donald Trump.

2. Hal ini menunjukkan bahwa abnormal return pada periode sesudah kemenangan Donald Trump memiliki nilai yang lebih kecil secara signifikan daripada sebelum peristiwa tersebut atau dengan kata lain, terjadi penurunan abnormal return yang signifikan sesudah kemenangan Donald Trump.

3. Volume perdagangan saham pada periode sesudah kemenangan Donald Trump tidak berbeda secara signifikan daripada periode sebelumnya.

\section{Saran}

Berdasarkan hasil penelitian ini, investor disarankan untuk senantiasa mempertimbangkan berbagai informasi yang relevan sebelum melakukan transaksi di pasar modal, termasuk informasi politik dari negara lain yang memiliki pengaruh yang kuat terhadap pasar modal di negara tempat investor tersebut akan melakukan transaksi. Dalam hal ini misalnya, investor Indonesia diharapkan untuk senantiasa turut mempertimbangkan informasi politik di AS karena negara tersebut memiliki pengaruh yang kuat terhadap pasar Indonesia. Setelah menerima berbagai informasi yang relevan, termasuk informasi politik, investor juga sebaiknya menganalisis informasi tersebut lebih lanjut agar hasil analisisnya dapat secara efektif membantu investor tersebut dalam mengambil keputusan yang tepat terkait kegiatan transaksi di pasar modal. 


\section{DAFTAR PUSTAKA}

Alwi, Z. I. 2008. Pasar Modal: Teori dan Aplikasi. Yayasan Pancur Siwah. Jakarta.

Bailey, W. dan Y.P. Chung. 1995. Exchange Rate Fluctuations, Political Risk, and Stock Returns: Some Evidence From an Emerging Market. Journal of Financial and Quantitatives Analysis. 30(4): 5-29.

Brown, S. dan J. Warner. 1985. Using Daily Return: The Case of Event Studies. Journal of Financial Economics. 1(4): 3-31.

Fama, E. F. 1970. Efficient Capital Markets: A Review Theory and Empirical Work. The Journal of Finance. 25(2): 383-417.

Husnan, S.2010. Dasar-Dasar Teori Portofollio dan Analisis Sekuritas. Edisi 5. UPP STIM YKPN.Yogyakarta.

Jogiyanto, H.M. 2016. Teori Portofolio dan Analisis Investasi. Edisi Kesepuluh. BPFE Yogyakarta. Yogyakarta.

Melati, M. dan A. Nurwulandari. 2017. Analisis Reaksi Pasar terhadap Stock Split pada Perusahaan Bertumbuh dan Tidak Bertumbuh. Jurnal Ilmu Manajemen Oikonomia. 13(2): 1-25.

Pratama, I.G.B., N.K. Sinarwati, dan N.A.S. Dharmawan. 2015. Reaksi Pasar Modal Indonesia terhadap Peristiwa Politik: Event Studi pada Peristiwa Pelantikan Joko Widodo sebagai Presiden Republik Indonesia ke-7. Jurnal Akuntansi Program S1. 3(1): 1-11.

Roszhandi, D. 2012. Bursa Efek Luncurkan Indeks IDX30. https://bisnis.tempo.com/read/398994/bursa-efek-luncurkan-indeks-idx30. $\quad 30$ September 2017 (15.30).

Sagita, V.D. 2017. Trump's Elected Shock Effect on Indonesian Stock Market. Journal of Indonesian Applied Economics. 6(1): 71-83.

Samsul, M. 2010. Pasar Modal dan Manajemen Portofolio. Erlangga. Surabaya.

Undang-Undang Republik Indonesia Nomor 21 Tahun 2011. Otoritas Jasa Keuangan. 22 November 2011. Lembaran Negara Republik Indonesia Tahun 2011 Nomor 111. Jakarta.

Undang-Undang Republik Indonesia Nomor 8 Tahun 1995. Pasar Modal. 10 November 1995. Lembaran Negara Republik Indonesia Tahun 1995 Nomor 64. Jakarta.

Wadrianto. 2016. 5 Negara dengan Ekonomi Terbaik di Dunia, Mana Saja?. www.liputan6.com/bisnis/read/3021277/5-negara-dengan-ekonomi-terbaik-didunia-mana-saja. 29 September 2017 (11.00). 
Wijanarko, I. 2012. Analisis Pengaruh Pemecahan Saham (Stock Split) terhadap Likuiditas Saham dan Retrun Saham. Skripsi. Program Studi Manajemen Universitas Diponegoro. Semarang. 